\title{
Applying and validating the PTVA-3 Model at the Aeolian Islands, Italy: assessment of the vulnerability of buildings to tsunamis
}

\author{
F. Dall'Osso ${ }^{1,2,4}$, A. Maramai ${ }^{3}$, L. Graziani ${ }^{3}$, B. Brizuela ${ }^{3}$, A. Cavalletti ${ }^{2,4}$, M. Gonella ${ }^{2,4}$, and S. Tinti ${ }^{5}$ \\ ${ }^{1}$ CIRSA, Interdepartmental Centre for Environmental Sciences Research, University of Bologna, via S. Alberto 163, \\ 48100 Ravenna, Italy \\ ${ }^{2}$ IDRA, Environmental Research Institute, via Kennedy 37, 44100 Ferrara, Italy \\ ${ }^{3}$ INGV, Istituto Nazionale di Geofisica e Vulcanologia, Via di Vigna Murata 605, 00143 Roma, Italy \\ ${ }^{4}$ Med Ingegneria S.r.l., Environmental Engineering, via P. Zangheri 16, 48124 Ravenna, Italy \\ ${ }^{5}$ University of Bologna, Department of Physics, Viale Carlo Berti Pichat 8, 40127 Bologna, Italy
}

Received: 17 March 2010 - Revised: 21 June 2010 - Accepted: 27 June 2010 - Published: 15 July 2010

\begin{abstract}
The volcanic archipelago of the Aeolian Islands (Sicily, Italy) is included on the UNESCO World Heritage list and is visited by more than 200000 tourists per year. Due to its geological characteristics, the risk related to volcanic and seismic activity is particularly high. Since 1916 the archipelago has been hit by eight local tsunamis. The most recent and intense of these events happened on $30 \mathrm{De}-$ cember 2002. It was triggered by two successive landslides along the north-western side of the Stromboli volcano (Sciara del Fuoco), which poured approximately $2-3 \times 10^{7} \mathrm{~m}^{3}$ of rocks and debris into the Tyrrhenian Sea. The waves impacted across the whole archipelago, but most of the damage to buildings and infrastructures occurred on the islands of Stromboli (maximum run-up $11 \mathrm{~m}$ ) and Panarea.

The aim of this study is to assess the vulnerability of buildings to damage from tsunamis located within the same area inundated by the 2002 event. The assessment is carried out by using the PTVA-3 Model (Papathoma Tsunami Vulnerability Assessment, version 3). The PTVA-3 Model calculates a Relative Vulnerability Index (RVI) for every building, based on a set of selected physical and structural attributes. Run-up values within the area inundated by the 2002 tsunami were measured and mapped by the Istituto Italiano di Geofisica e Vulcanologia (INGV) and the University of Bologna during field surveys in January 2003. Results of the assessment show that if the same tsunami were to occur today, 54 buildings would be affected in Stromboli, and 5 in Panarea. The overall vulnerability level obtained in this analysis for Stromboli and Panarea are "average"/"low" and "very low", respectively. Nonetheless, 14 buildings in Strom-
\end{abstract}

Correspondence to: F. Dall'Osso

(filippodallosso@gmail.com) boli are classified as having a "high" or "average" vulnerability. For some buildings, we were able to validate the RVI scores calculated by the PTVA-3 Model through a qualitative comparison with photographs taken by INGV and the University of Bologna during the post-tsunami survey. With the exception of a single structure, which is partially covered by a coastal dune on the seaward side, we found a good degree of accuracy between the PTVA-3 Model forecast assessments and the actual degree of damage experienced by buildings. This validation of the model increases our confidence in its predictive capability. Given the high tsunami risk for the archipelago, our results provide a framework for prioritising investments in prevention measures and addressing the most relevant vulnerability issues of the built environment, particularly on the island of Stromboli.

\section{Introduction}

The Aeolian archipelago, located in the south Tyrrhenian Sea to the west of Calabria and to the north of Sicily, is made up of seven major islands. It is located about eleven nautical miles off the northern Sicily coast, in the province of Messina (Fig. 1). The total number of residents is about 13500 , with most living on Lipari. The archipelago is listed as an UNESCO World Heritage site and attracts more than 200000 tourists per year, mostly in the summer months. Therefore, from May to September, the number of people living in the archipelago can increase by as much as five times.

In the context of the geodynamical evolution of the Mediterranean basin, the collision between the African and Eurasian plates created a marginal "fore-arc deep-basin" system of which the Aeolian Islands represent the volcanic

Published by Copernicus Publications on behalf of the European Geosciences Union. 


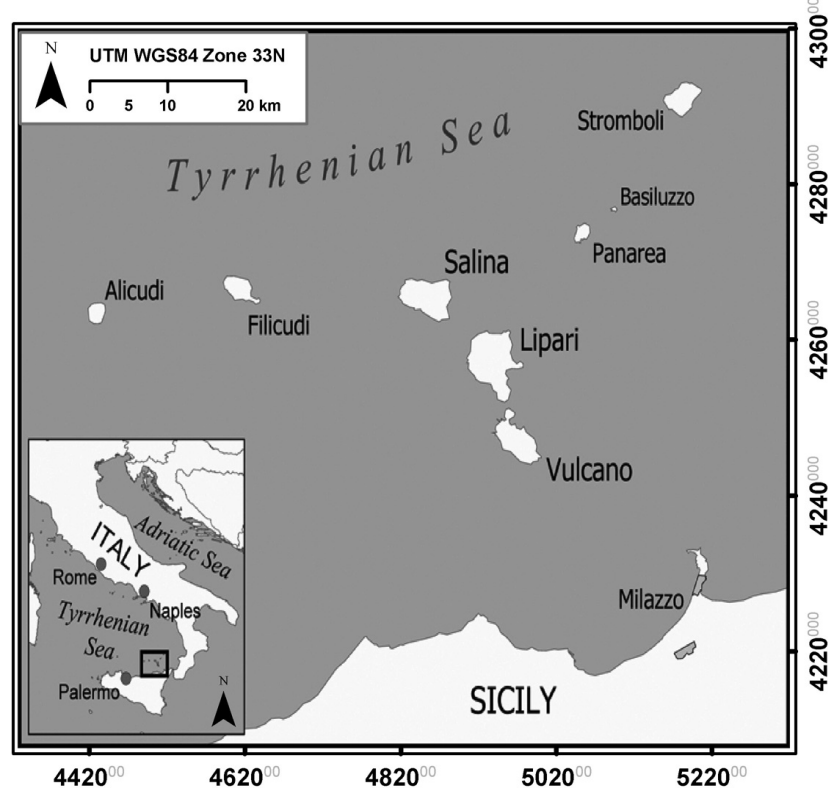

Fig. 1. Geographic location of the study area. The Aeolian archipelago includes, from west to east, the islands of: Alicudi, Filicudi, Salina, Lipari, Vulcano, Panarea and Stromboli (http://whc.unesco.org, modif.).

front. All the islands were submarine volcanoes emerged about $700 \mathrm{ky}$ ago and, together with the eight seamounts (Marsili, Glauco, Sisifo, Enarete, Eolo, Lamentini, Alcione, Palinuro), they constitute the Aeolian Volcanic District which extends for a total length of about $200 \mathrm{~km}$ along the north-western margin of the Calabria Arc and the southern limit of the Tyrrhenian Retro-Arc Basin (Barberi et al., 1973; Beccaluva et al., 1985).

The volcanism of the Aeolian Islands started during the Pleistocene, with two main phases of activity (Maramai et al., 2005a). The volcanic edifice of Panarea, the oldest in the archipelago, and the islands of Filicudi, Alicudi, part of Salina and Lipari all originated during the first phase in the early Pleistocene. The second phase started, after a period of dormancy, in the upper Pleistocene, with the completion of Lipari and Salina Islands and the creation of Volcano and Stromboli Islands (Maramai et al., 2005a). Stromboli is the most active volcano in the archipelago and its activity consists of almost continuous low energy explosions with ejection of magmatic scoriae from the eruptive vents located inside the crater. Significant eruptions and/or explosions happen frequently and are often accompanied by earthquakes, landslides and sometimes tsunamis. The activity of the Stromboli volcano seems to be continuous since about 1000-1500 years ago (Rosi et al., 2000). The summit of the volcano reaches an elevation of $926 \mathrm{~m}$, while the volcanic edifice extends below the sea level to a depth of $1200-1500 \mathrm{~m}$ on the east and south flanks and 1700-2200 m on the north and west flanks. One of the main features of the volcano is a deep scar located on the north-western flank, called Sciara del Fuoco, caused by several flank collapses that have occurred during the past 5000 years (Pasquarè et al., 1993).

The nature of Stromboli's volcanic activity is well-defined and has given rise to the term "Strombolian activity", to describe similar behaviour observed in other volcanoes around the world (Burton et al., 2007; http://volcanoes.usgs.gov/ images/pglossary/strombolian.php). This activity is characterised by rhythmic mild gas explosions, occurring at time steps of about 10-20 min, ejecting ash, incandescent crystalrich scoriae and blocks (Burton et al., 2007). On Stromboli this activity is interspersed with "major explosions" which are more energetic events involving the ejection of lava bombs and blocks, that can reach distances of several hundreds of $m$ away from the vent, and also lapilli and ash that can be expelled several kilometres away. Major explosions can become very energetic and last from several hours to a few days. In these cases they are called "paroxysms" and result in showers of incandescent scoriae and bombs that are violently ejected to distances of several kilometres away. Paroxysms usually occur at intervals of years or decades (Barberi et al., 1993; Rosi et al., 2000) and during these phases huge amounts of erupted material can accumulate on the volcano flanks. These deposits can become unstable, collapsing into the sea and triggering tsunamis.

\subsection{Record of tsunamis at the Aeolian Islands}

The scientific community has developed a systematic interest in the Aeolian volcanoes since the end of the 19th century, and with regard to tsunamis the first reliable information of events occurred in the Aeolian Islands dates back to 1916. Since then eight tsunami events, either destructive or minor, have affected the archipelago, being almost all directly or indirectly related to volcanic activity (Maramai et al., 2005a). Six of the eight tsunamis, including the strongest one, were caused by the volcanic activity of the Stromboli volcano. One occurred on Salina Island and was associated with a local earthquake, and one was generated by a landslide on the flank of Vulcano Island.

A study of the Aeolian tsunamis was published by Maramai et al. (2005a) detailing seven historical events in the period of 1916 to 1988, whereas the last and most destructive tsunami (30 December 2002 Stromboli event), is widely described in many papers (Pino et al., 2004; Maramai et al., 2005b; Tinti et al., 2005, 2006a,b).

A summary of the Aeolian tsunamis with the main tsunami parameters (time, source area, coordinates, cause, tsunami intensity, and description) is given in Table 1 (from Maramai et al., 2005a, modified). 
Table 1. Summary of Aeolian tsunamis with main tsunami parameters: time, source area, coordinates, cause, tsunami intensity, and description ( $c$ = intensity of the tsunami due to the hot avalanche at Piscità; $d=$ intensity of the tsunami observed in Punta Lena and in San Vincenzo; $\mathrm{e}=$ intensity of the tsunami observed in the Sciara del Fuoco; $\mathrm{f}=$ intensity of the tsunami observed in Forgia Vecchia). The tsunami intensity is expressed in the Sieberg-Ambraseys scale (Sieberg, 1927; Ambraseys, 1962).

\begin{tabular}{|c|c|c|c|c|c|c|}
\hline Year & Month & Day & $\begin{array}{l}\text { Source- } \\
\text { area }\end{array}$ & Cause & $\begin{array}{l}\text { Tsunami } \\
\text { intensity }\end{array}$ & $\begin{array}{l}\text { Short } \\
\text { description }\end{array}$ \\
\hline 1916 & 7 & 3 & Stromboli & $\begin{array}{l}\text { Speculated submarine } \\
\text { landslide in the Sciara } \\
\text { del Fuoco }\end{array}$ & 2 & $\begin{array}{l}\text { Sea retreat and flooding of Spiagga } \\
\text { Longa beach, N. Stromboli }\end{array}$ \\
\hline 1919 & 5 & 22 & Stromboli & $\begin{array}{l}\text { Speculated submarine } \\
\text { landslide in the Sciara } \\
\text { del Fuoco }\end{array}$ & 3 & $\begin{array}{l}\text { In Stromboli, sea retreat by } 200 \mathrm{~m} \text { and } \\
\text { flooding of the beach. Boats carried } \\
300 \mathrm{~m} \text { inland in to the vineyards. }\end{array}$ \\
\hline 1926 & 8 & 17 & Salina & $\begin{array}{l}\text { Speculated submarine landslide } \\
\text { associated with an earthquake }\end{array}$ & 2 & Initial sea retreat at Salina. \\
\hline 1930 & 9 & 11 & Stromboli & $\begin{array}{l}\text { Double event: one caused } \\
\text { by an observed hot avalanche } \\
\text { at Piscità and one by a specu- } \\
\text { lated submarine landslide }\end{array}$ & $2 \mathrm{c} 4 \mathrm{~d}$ & $\begin{array}{l}\text { A hot avalanche raised waves that scalded } \\
\text { and killed one man in the Eolo's grotto } \\
\text { (northern Stromboli). Landslide induced } \\
\text { tsunami: sea retreat by } 100 \mathrm{~m} \text { followed by } \\
\text { inundation of Sopra Lena beach up to } 200 \mathrm{~m} \\
\text { inland (NE Stromboli). One man killed at San } \\
\text { Vincenzo (NE Stromboli) by } 2.5 \text {-m-high waves. } \\
\text { On the Calabrian coast, wave of } 2-3 \text { m observed. }\end{array}$ \\
\hline 1944 & 8 & 20 & Stromboli & $\begin{array}{l}\text { Double event: one caused by } \\
\text { a speculated mass failure } \\
\text { concomitant with an observed } \\
\text { lava flow at Sciara del Fuoco, } \\
\text { and onecaused by an observed } \\
\text { hot avalanche at Forgia Vecchia }\end{array}$ & $2 \mathrm{e} 4 \mathrm{f}$ & $\begin{array}{l}\text { Big waves in the Sciara del Fuoco area. } \\
\text { Big waves on the East coast of Stromboli. } \\
\text { One house destroyed. } \\
\text { Beach full of fish. }\end{array}$ \\
\hline 1954 & 2 & 2 & Stromboli & $\begin{array}{l}\text { Speculated submarine } \\
\text { landslide in SE coast }\end{array}$ & 3 & $\begin{array}{l}\text { Initial sea retreat followed by waves } \\
\text { in E. Stromboli. Boats carried inland. }\end{array}$ \\
\hline 1988 & 4 & 20 & Vulcano & $\begin{array}{l}\text { Observed subaerial landslide } \\
\text { in NE flank of La Fossa }\end{array}$ & 2 & $\begin{array}{l}\text { Wave } 1-2 \mathrm{~m} \text { high in the source area. Wave } \\
\text { with } 0.5-\mathrm{m} \text { amplitude in Vulcano harbour. }\end{array}$ \\
\hline 2002 & 12 & 30 & Stromboli & $\begin{array}{l}\text { Double landslides (subaerial } \\
\text { and submarine) in the Sciara } \\
\text { del Fuoco flank }\end{array}$ & 5 & $\begin{array}{l}\text { Both landslides produced tsunami waves: } \\
\text { the first event was characterised by } \\
\text { an initial negative sea movement, while } \\
\text { the second produced a positive wave. } \\
\text { A destructive tsunami, starting with } \\
\text { an initial slow withdrawal, violently } \\
\text { inundated the northern coasts of } \\
\text { the island with three-four big waves. } \\
\text { Max. runup: } 11 \mathrm{~m} \text {. Severe damage to many } \\
\text { buildings on Stromboli Island and some } \\
\text { damage in the Panarea Island. The waves } \\
\text { propagated up to the Ustica Island, } \\
\text { the northern Sicily and Campania coasts. }\end{array}$ \\
\hline
\end{tabular}

\subsection{The tsunami of 30 December 2002}

The Stromboli tsunami on 30 December 2002 is the largest known event ever reported in the Aeolian archipelago.
In the second half of 2002 the Stromboli volcano saw an increase in its explosive activity, that lasted until 28 December, when a new effusive phase made the Sciara del Fuoco flank unstable. Two days later, on 30 December, two major landslides occurred, one submarine and the other subaerial, which triggered tsunami waves. The first slide occurred at 


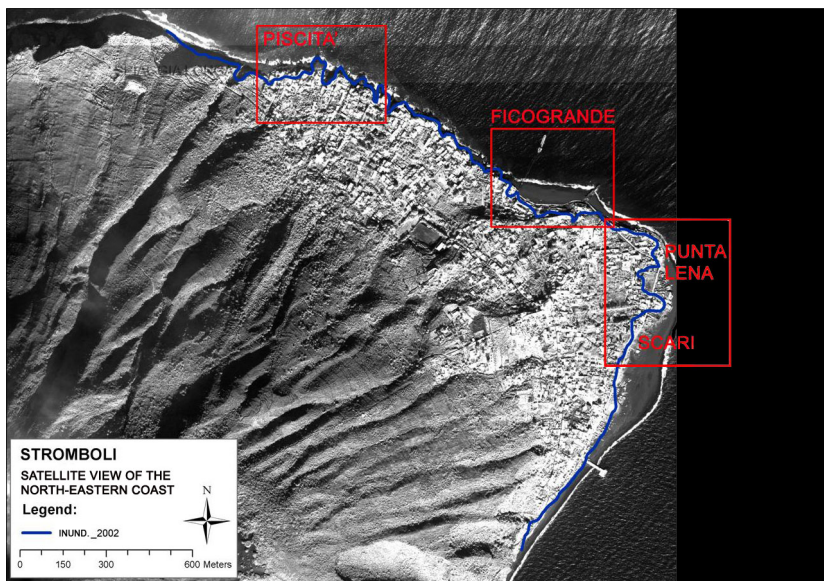

Fig. 2. A "Worldview" satellite image of the north-eastern coast of Stromboli Island. Main administrative divisions are highlighted with red frames. The blue line marks the limit of maximum inundation caused by the 2002 tsunami.

13:15 local time (LT) and the second one about 7-8 min later, with a subaerial detachment of a mass of about $7-8 \times 10^{6} \mathrm{~m}^{3}$ from the Sciara del Fuoco. The total volume of transported material during the two slides was about $2-3 \times 10^{7} \mathrm{~m}^{3}$ (Baldi et al., 2003; Bosman et al., 2003; Chiocci et al., 2003).

The 30 December tsunami was studied by several researchers and many post-event field surveys were carried out by national and international teams in order to get a detailed picture of the effects. On the basis of eye-witness accounts, Tinti et al. (2005) established that both landslides generated a tsunami. The first sea movement, caused by the submarine slide, was a withdrawal. With regard to the second landslide, the nature of the initial sea movement is unclear.

The first wave arrived about $3 \mathrm{~min}$ after the landslide as the sea water flooded Ficogrande beach (Fig. 2), and one minute later Punta Lena and Scari were inundated and severely damaged. A sea surface withdrawal was observed on the island of Panarea (Fig. 1) at 13:20 LT, about 5 min after the initial tsunami generation. Afterwards, two or three strong sea swells inundated a part of San Pietro harbour. In less than 20 min all the Aeolian Islands had been struck by the tsunami and anomalous sea movements were later observed in Milazzo, on the northern Sicilian coast, about $60 \mathrm{~km}$ south of Stromboli (Tinti et al., 2006a; Maramai et al., 2005b).

The post-tsunami field surveys, performed according to the field procedures adopted by the international tsunami community (IOC/UNESCO, 1998), allowed researchers to describe damage and effects along the coasts of the Aeolian archipelago. In particular, the surveys were focused on the coast of Stromboli, Panarea, Lipari, Vulcano and Salina Islands where major effects were expected.
The north-eastern coast of Stromboli was the most severely affected by the tsunami, with run-up ranging from 3 to $11 \mathrm{~m}$. Severe effects were observed at Ficogrande, Piscità and Punta Lena (Fig. 2) where buildings fronting the sea were heavily damaged.

At Scari (Fig. 2), the tsunami effects were less severe and only few buildings on the beach were damaged, although the maximum inland inundation $(135 \mathrm{~m})$ was recorded here, most probably because of the low beach slope.

On Panarea Island the inundation caused some damage to a few structures on the beach, particularly in the harbour of San Pietro, where INGV measured the maximum runup $(2.3 \mathrm{~m})$ and inundation $(36.5 \mathrm{~m})$ recorded on the island.

Tsunami effects were also observed on all the other islands of the archipelago where eyewitness reports described anomalous sea behaviour, mainly as extraordinary tides or whirlpools.

\subsection{Aim of this work}

The aim of this work is to assess the vulnerability of existing buildings in the Aeolian Islands to a future tsunami. The assessment was carried out using the latest version of the Papathoma Tsunami Vulnerability Assessment Model (PTVA3 Model), recently developed by Dall'Osso et al. (2009a,b). The PTVA-3 Model calculates a Relative Vulnerability Index (RVI) for every inundated structure.

Since no probabilistic assessments for estimating tsunami risk are available for the study area, our approach is deterministic. The inundation scenario we adopt is the 2002 event. As a consequence, we calculate what would be the vulnerability level of buildings if the 2002 tsunami occurred again. Accordingly, the analysis is carried out only for those structures that are currently located within the area inundated in 2002. Apart from a few recent structures, those buildings are the same that were hit in 2002. For some of the inundated buildings, we could compare RVI values determined during our assessment with photographs of the damage suffered during the 2002 tsunami. This provides an important opportunity to "validate" the damage forecast potential of the PTVA-3 Model against actual damage sustained during a real tsunami event.

\section{Applying the Papathoma Tsunami Vulnerability Assessment Model (PTVA-3 Model)}

\subsection{The PTVA Model: description, applications and competing methods}

The PTVA Model (Papathoma and Dominey-Howes, 2003; Papathoma et al., 2003) is a GIS based method developed to assess the vulnerability to tsunamis of single buildings. It is able to calculate a Relative Vulnerability Index (RVI) for each building within the inundation zone. RVIs are obtained as mathematical functions of different attributes contributing to the overall building vulnerability. The main attributes are 
grouped as follows:

- the physical attributes of the building known to be associated with the degree of damage suffered during past tsunamis (e.g. number of storeys, building material, foundations, ground floor hydrodynamics, movable objects etc.);

- the environment surrounding each building (e.g. degree of protection provided to the building by natural or artificial barriers);

- the depth of water expected at the building location.

The PTVA Model requires all of the necessary building attributes to be entered as numerical scores. Scores are given to each attribute according to its contribution to the overall building vulnerability. For example, if a building has a reinforced concrete structure the "building material" attribute will score lowest, given that reinforced concrete structures are the least vulnerable to tsunami impact (if all other attributes are equal). The PTVA Model provides specific tables that state which score must be given to the different building attributes (e.g. for a reinforced concrete structure, the "building material" score would be -1 ; for a wooden structure, the "building material" score would be +1 , etc.). After being entered, attribute scores are used by the model to calculate RVI scores. Importantly, RVI scores do not depend on the economic value of buildings, nor on the value of their contents (e.g. the furniture). To the PTVA Model, each building is equally important, since its value is based only on the structural-functional service it provides.

The first version of the PTVA Model (PTVA-1) was developed and successfully tested in a case study in the Gulf of Corinth, Greece (Papathoma and Dominey-Howes, 2003; Papathoma et al., 2003). After the 2004 Indian Ocean Tsunami, the model was upgraded to version \#2 (PTVA-2) and validated using data from field surveys at the Maldives (Dominey-Howes and Papathoma, 2007). Dominey-Howes et al. (2010) have recently tested the PTVA-2 Model in the Cascadia subduction zone (Seaside, Oregon, US). In such case study, the model was coupled for the first time with a probabilistic tsunami hazard assessment and RVI scores were used to calculate Probable Maximum Losses (PMLs) associated with a 1:500 year tsunami inundation, demonstrating the flexibility and usefulness of the PTVA approach.

The newest version of the model is the PTVA-3, recently developed by Dall'Osso and Dominey Howes (2009b) and applied to the coastal zones of Sydney (Australia) (Dall'Osso et al., 2009a,b). PTVA-3 takes account of the latest published data about attributes that affect building vulnerability to tsunamis and introduces the Analytic Hierarchy Process (AHP) for weighting the various attributes, in order to limit concerns about their subjective ranking in the original model. A similar approach, based on the AHP, was applied by Dall'Osso et al. (2006) within the CRATER project (Coastal
Risk Analysis for Tsunami and Environmental Remediation), developed in partnership with INGV. The improvement of the CRATER approach and its integration within the PTVA2 lead to the development of PTVA-3 Model.

To our knowledge, the only existing method similar to the PTVA is the one proposed by Omira et al. (2009), which has the important advantage of integrating a numerical simulation of the tsunami flooding. However, Omira's approach considers a smaller number of building attributes, excluding in particular those related to building surroundings (e.g. natural barriers, the shielding effect provided by other buildings, the presence of large movable objects) which were found to be very influential on the final level of damage observed after past tsunamis (Dominey-Howes and Papathoma, 2007; Reese et al., 2007; Olwig et al., 2007; Matsutomi et al., 2006; Tanaka et al., 2006). Further, Omira et al. (2009) divide the exposed buildings in different classes according to their main structural characteristics, and give the same score (the "classification factor") to all the buildings of the same class. This methodology has the advantage to reduce the amount of input data needed and time required for field surveys, but strongly depends on the architectural/engineering context of the study area and it may cause some biases for those buildings that have mixed features and cannot be univocally assigned to any of the classes. In the PTVA Model, such issue is addressed as all building attributes are scored and weighted independently, and there are no pre-selected building categories.

\subsection{Data gathering: building the GIS}

Almost all of the structures within the area inundated by the 2002 tsunami were located on the island of Stromboli, the exceptions being a few buildings at the San Pietro harbour (Panarea). In order to apply the PTVA-3 Model, we gathered information about the following building attributes:

1. building material;

2. number of storeys;

3. hydrodynamics of the ground-floor (totally closed by walls, few small windows, high number of windows, columns and open spaces, etc.);

4. foundation type;

5. preservation condition;

6. number of underground levels;

7. protective structures along the shoreline (e.g. sea-walls, rocks, other fences, etc.);

8. artificial barriers close to the building (e.g. brick wall around the garden); 


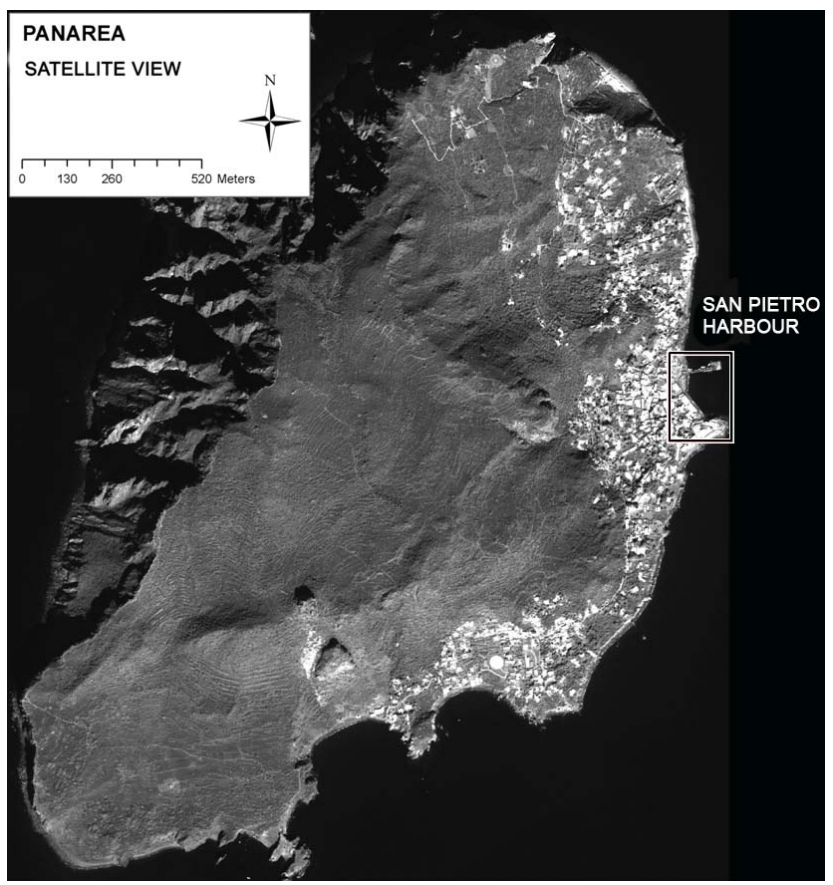

Fig. 3. A "Worldview" satellite image of Panarea Island. The frame indicates the harbour of San Pietro, where five buildings were inundated during the 2002 tsunami. Given the small flooded area, the inundation line was not recorded on Panarea Island.

9. building use (residential, commercial, tourism, Public Administration, etc.);

10. orientation of the building with respect to the expected or observed flow direction;

11. natural barriers between the building and the sea (e.g. vegetation, sand dunes, etc.);

12. number of other buildings located between the considered building and the sea (to assess the shielding effect);

13. movable objects between the building and the sea (car parks, boats, etc.).

Given the high number of required data points, we extracted spatial data from two "Worldview" satellite images. Worldview images provide a geometrical resolution of $60 \mathrm{~cm}$ and are suitable for the analysis of the built environment through a photo-interpretation process. We selected one image for Stromboli (Fig. 2) and one for Panarea (Fig. 3), using the following search filters:

- images registered after 2008;

- minimal cloud cover (all of the buildings had to be clearly recognizable);

- good brightness/contrast ratio.
Elevation data was sourced using as a reference a Digital Elevation Model (DEM) provided by the University of Bologna, with a geometrical resolution of $10 \mathrm{~m}$ and a vertical accuracy better than $1 \mathrm{~m}$.

Once orthorectified, Worldview images and the DEM were imported into a GIS and used as geographical base of reference. We used the DEM and the tsunami inundation measures undertaken by INGV and by the University of Bologna in 2003 to identify all of the exposed buildings and to calculate the depth of inundation expected to hit each of them. Buildings located within the inundation zone were manually digitised within the GIS as polygons. Afterwards, we entered the inundation depth measured after the 2002 tsunami into the attribute table of every polygon (building).

Building attributes 10 to 13 of the aforementioned attribute list (e.g. building orientation with respect to the expected flow direction, natural barriers, etc.) were obtained through a photo-interpretation process of the Worldview images. Remaining attributes (from numbers 1 to 9 ) have been gathered building by building through field surveys.

After field surveys, all attribute data were converted into numerical scores, and manually entered into the GIS.

\subsection{Adapting the PTVA-3 Model to the construction standards of the Aeolian Islands}

The structure of the PTVA-3 Model has been conceived to be applicable anywhere, however a few elements depend on boundary conditions (type of architecture, inundation scenario) and might need to be adapted to specific cases.

In this work, the only adaptation we introduced involves the "building material" attribute, since construction standards and typical materials used in the Aeolian Islands are different from those observed in Australia, where the PTVA3 Model was firstly developed.

In the Aeolian Islands most of the buildings have walls made of a single layer of bricks, with a thickness between 15 and $30 \mathrm{~cm}$. Some of the oldest structures have walls made of volcanic rocks (e.g. pumice stone) that are poorly cemented and weathered. Some of the newest structures are built with reinforced concrete frames and brick fillings, while a few buildings are made of wood or corrugated iron.

In order to integrate those construction standards into the model, scores to the "building material (m)" attribute have been given according to Table 2 .

\subsection{Running the PTVA-3 Model: the "inundation vulnerability" tool for ESRI ArcGIS 9}

Once attribute data have been gathered and entered into the GIS as numerical scores, the relative vulnerability of every building is automatically calculated through the application of a specific add-on developed for ESRI ArcGIS 9, called "inundation vulnerability" tool. 
Table 2. Scores given to the attribute "m" (building material). These scores have been modified with respect to the original PTVA-3 Model in order to fit with the typical construction standards used at the Aeolian Islands.

\begin{tabular}{lccccc}
\hline Score of the attribute "m" & -1 & -0.5 & 0 & +0.5 & +1 \\
\hline $\begin{array}{l}\text { Construction } \\
\text { material }\end{array}$ & $\begin{array}{c}\text { reinforced } \\
\text { concrete }\end{array}$ & $\begin{array}{c}\text { bricks with thickness } \\
\text { between } 15 \text { and } 30 \mathrm{~cm}\end{array}$ & $\begin{array}{c}\text { bricks with thickness } \\
\text { up to } 15 \mathrm{~cm}\end{array}$ & $\begin{array}{c}\text { poorly cemented } \\
\text { natural rocks }\end{array}$ & wood or \\
corrugated iron
\end{tabular}

Table 3. Summary of the total number of buildings by building class and the number of buildings according to their Relative Vulnerability Index (RVI) scores in Stromboli Island.

\begin{tabular}{|c|c|c|c|c|c|c|}
\hline \multicolumn{2}{|c|}{ Stromboli Island } & \multicolumn{5}{|c|}{ RVI scores } \\
\hline $\begin{array}{l}\text { Building } \\
\text { class type }\end{array}$ & $\begin{array}{l}\text { Number of inundated } \\
\text { buildings of each } \\
\text { class type }\end{array}$ & $\begin{array}{l}\text { Buildings with } \\
\text { "Very Low" } \\
\text { RVI }\end{array}$ & $\begin{array}{l}\text { Buildings with } \\
\text { "Low" } \\
\text { RVI }\end{array}$ & $\begin{array}{l}\text { Buildings with } \\
\text { "Average" } \\
\text { RVI }\end{array}$ & $\begin{array}{l}\text { Buildings with } \\
\text { "High" } \\
\text { RVI }\end{array}$ & $\begin{array}{l}\text { Buildings with } \\
\text { "Very High" } \\
\text { RVI }\end{array}$ \\
\hline Residential & 38 & 9 & 17 & 8 & 4 & - \\
\hline Commercial & 10 & 1 & 8 & 1 & - & - \\
\hline Tourism & 4 & 2 & 2 & - & - & - \\
\hline Utility & 1 & - & 1 & - & - & - \\
\hline Public administration & 1 & - & - & 1 & - & - \\
\hline Health & - & - & - & - & - & - \\
\hline Education & - & - & - & - & - & - \\
\hline Public transport & - & - & - & - & - & - \\
\hline Recreation and culture & - & - & - & - & - & - \\
\hline Total & 54 & 12 & 28 & 10 & 4 & 0 \\
\hline
\end{tabular}

The "inundation vulnerability" tool was created by Dall'Osso and Dominey-Howes (2009a) during the first application of the PTVA-3 Model (Dall'Osso et al., 2009a). Once input attribute levels are entered into the GIS in the correct format, the tool is able to perform all calculations required to obtain the final RVI value of each building.

Readers interested in further details about the structure and the application of the "inundation vulnerability" tool can refer to the user's manual (Dall'Osso and Dominey Howes, 2009a).

\section{Results}

The results show that if the 2002 tsunami occurred again, 54 buildings would be hit on Stromboli, and 5 on Panarea. All of these buildings are currently located within the area inundated in 2002, as indicated by the INGV and the University of Bologna post-tsunami surveys.

As in previous PTVA-3 Model applications (Dall'Osso et al., 2009a,b) RVI values have been grouped into the following five classes:

$$
\begin{aligned}
& \text { - RVI = "very high" } \\
& \text { - RVI = "high" } \\
& \text { - RVI = "average" } \\
& \text { - RVI = "low" }
\end{aligned}
$$

$$
\text { - RVI = "very low" }
$$

Surveyed buildings and their RVI scores have been stored within a GIS and displayed in vulnerability maps, having a scale such that every single structure and its surroundings can be clearly indentified. The coastal area inundated by the 2002 tsunami has been fully covered by 4 different map layouts (3 for Stromboli and 1 for Panarea), corresponding to the following administrative divisions (Figs. 2 and 3):

$$
\begin{aligned}
& \text { 1. Stromboli Island - Piscità } \\
& \text { 2. Stromboli Island - Ficogrande } \\
& \text { 3. Stromboli Island - Punta Lena and Scari } \\
& \text { 4. Panarea Island - San Pietro harbour }
\end{aligned}
$$

In our study, we created several vulnerability maps for each division: one map displaying an overview of all affected buildings, and one for each of the building use categories observed during field surveys (i.e. residential, commercial, tourism, Public Administration and utility). For the sake of brevity, we present here just one overview-map per division, showing all types of buildings. However, Table 3 provides a summary of the total number of inundated buildings by their use and the number of buildings according to their RVI score for Stromboli Island. 


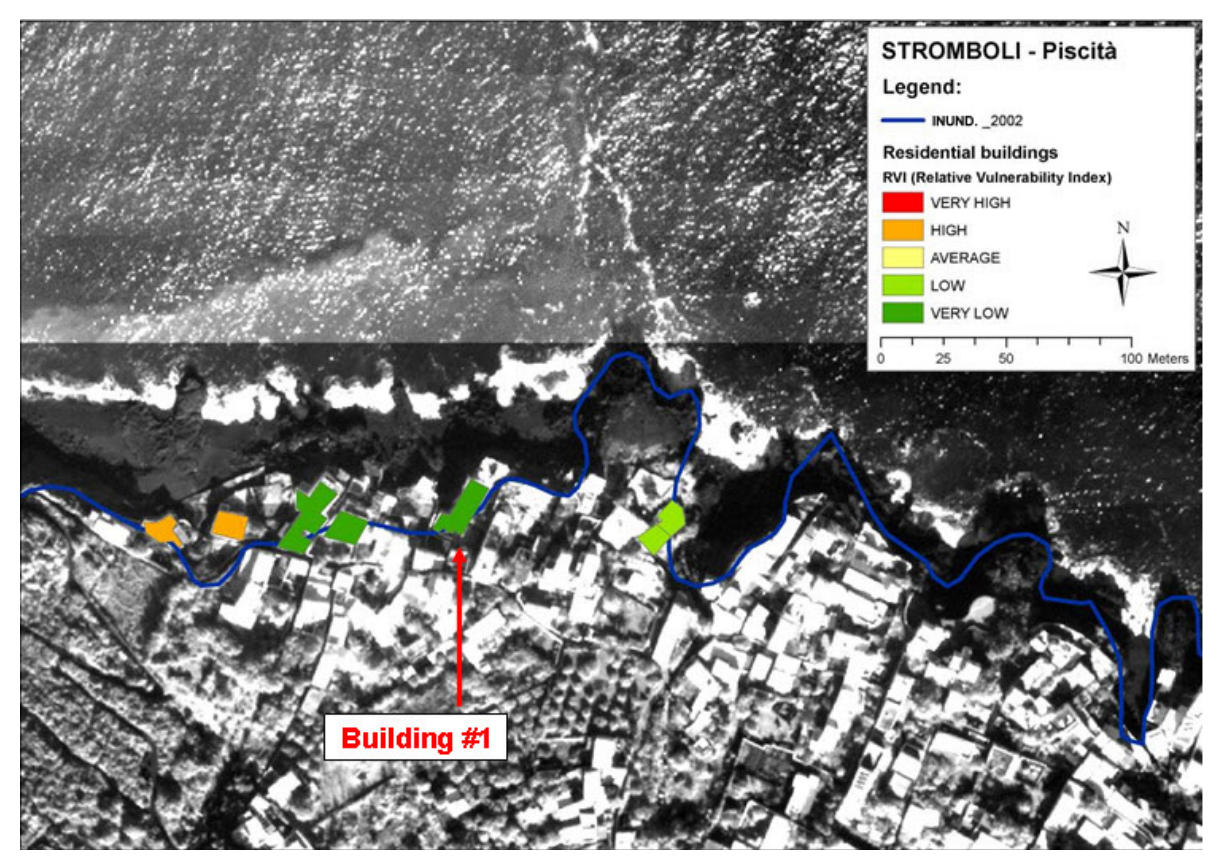

Fig. 4. Vulnerability map of Piscità (Stromboli Island). The map layout corresponds to the red frame in Fig. 2. The blue line marks the limit of maximum inundation caused by the 2002 tsunami. Building \#1 has been used to validate PTVA-3 Model results. A picture of damage suffered by building \#1 during the 2002 tsunami is shown in Fig. 8.

\subsection{Stromboli - Piscità}

At Piscità the tsunami would strike seven residential buildings (Fig. 4). Two are located just behind a pocket beach and would be flooded by more than $2 \mathrm{~m}$ of water. Their respective RVI scores are "high". The five remaining houses have "low" and "very low" RVI scores. Whilst they have similar construction characteristics, they all sit on the coastal cliff, where the maximum inundation depth would not exceed $1 \mathrm{~m}$.

\subsection{Stromboli - Ficogrande}

In Ficogrande the total number of inundated buildings would be 27 (Fig. 5). Six of them have "very low", 17 "low", and four "average" RVI values. The main issues of concern for the area are the four residential structures located just in front of the beach, at the eastern end of the bay. These buildings are one storey brick houses, with a partially closed groundfloor, few windows and no protection from the sea. According to the inundation scenario, they would experience a flow depth between 1 and $2 \mathrm{~m}$.

At the western end of the bay, buildings include an hotel, shops and restaurants. Most of them are built according to new construction standards, with reinforced concrete structures, two or more storeys and open ground-floors with large panoramic windows. The inundation depth on that side of the beach would be in the order of $1 \mathrm{~m}$. According to the PTVA-3 Model, the RVIs of such buildings range between "low" and "very low".

\subsection{Stromboli - Punta Lena and Scari}

The tsunami would hit 20 buildings in this part of the island. Two out of them are classified as having a "high" RVI score, six have an "average", nine have a "low" RVI and three have a "very low" RVI (Fig. 6).

The average vulnerability in Punta Lena is higher than in Ficogrande. Although buildings here have similar construction characteristics, they are much closer to the sea and would be affected by a deeper flow. Furthermore, several sources of big movable objects have been observed along the shoreline (car and bike deposits, containers, boats, etc.). Those objects might be dragged by the tsunami against the first row of buildings, causing heavier damage.

Most of the buildings (14) in this area are residential. Two of them have a "high" RVI score. The one at the northern end has a concrete structure, but only one floor, with no openings at all. It would be hit by a wave higher than $3 \mathrm{~m}$. The southernmost one, in Scari, is built with bricks ( $15 \mathrm{~cm}$ thick walls), has two storeys and the ground-floor is completely closed. Water depth impacting this building would be between 2 and $3 \mathrm{~m}$.

Residential buildings with "average" RVIs account for 4 of the 20 structures. They are all houses built on the shoreline, with construction characteristics similar to the previous two buildings (those having a "high" RVI), but with a lower expected water depth. Some of them have vulnerability scores reflecting better protection. 


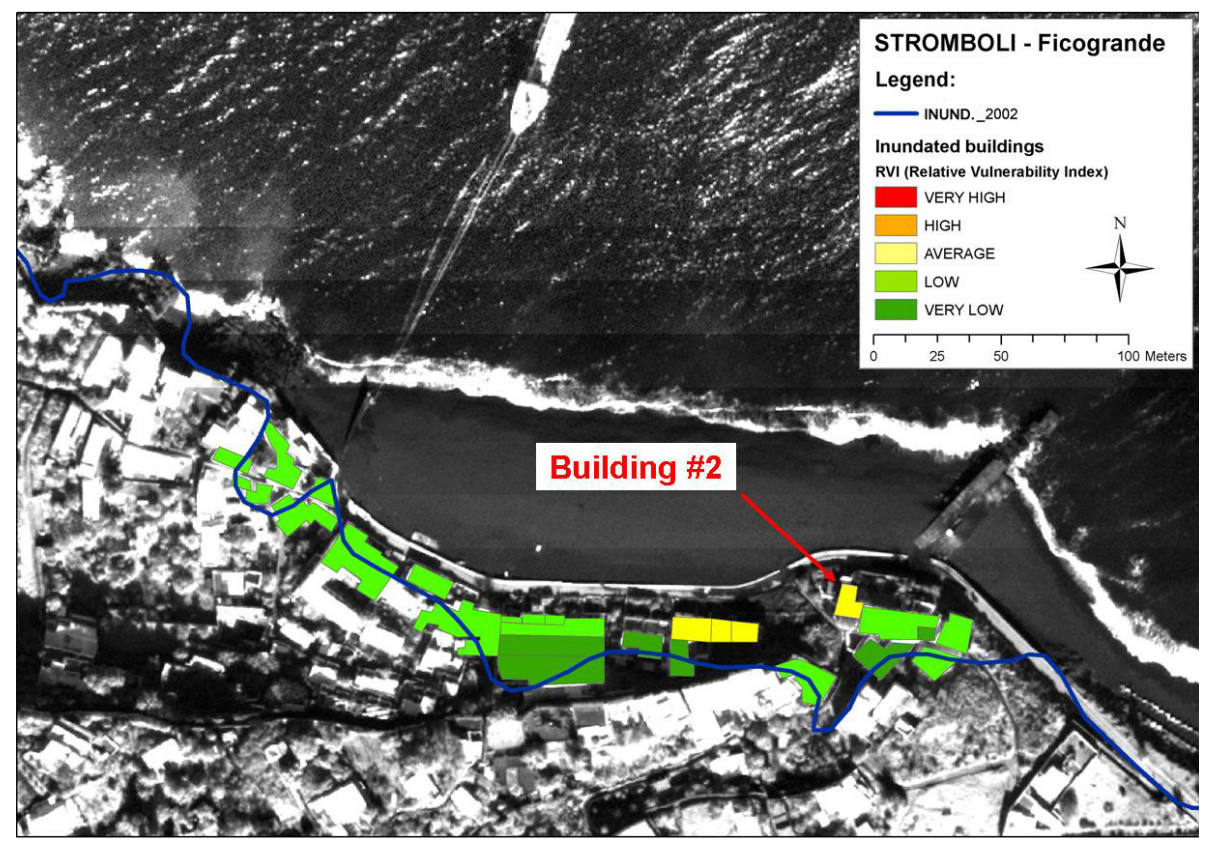

Fig. 5. Vulnerability map of Ficogrande (Stromboli Island). The map layout corresponds to the red frame in Fig. 2. The blue line marks the limit of maximum inundation caused by the 2002 tsunami. Building \#2 has been used to validate PTVA-3 Model results. Two pictures of damage suffered by building \#2 during the 2002 tsunami are shown in Fig. 9.

Only 4 commercial buildings would be inundated in Punta Lena and Scari. One of them in Scari, a long warehouse made of corrugated iron, has an "average" RVI score.

The only "utility" building of the whole island is a public electric power station, located in the southern part of Scari (Fig. 6): it would be flooded by less than $1 \mathrm{~m}$ of water and its RVI score is "low".

\subsection{Panarea - San Pietro harbour}

On the island of Panarea the only area inundated by the 2002 tsunami was San Pietro harbour (Fig. 7). Post-tsunami surveys undertaken by INGV reported a maximum run-up of $1 \mathrm{~m}$ just behind the harbour pier. Given the small flooded area, the inundation line was not recorded for the San Pietro harbour and therefore is not shown in Figs. 3 and 7. We analysed five commercial buildings (three shops and two cafès). They all have very similar construction characteristics: two storeys, brick-walls and a partially open ground-floor with doors and windows. Objects such as tables, chairs and boats are usually located between the buildings and the shoreline. These objects could increase the impact load, but the RVI scores are all "very low" (Fig. 7).

\section{Discussion and recommendations}

The application of the PTVA-3 Model at Aeolian Islands showed that the majority of exposed buildings is located on the island of Stromboli (54 buildings) while just five structures would be inundated at San Pietro harbour, on Panarea.
On Stromboli Island, nearly three quarters $(74 \%)$ of all affected buildings have been classified as having a "very low" or "low" RVI score, while all of the five structures on Panarea have "very low" RVIs.

The most problematic buildings are 4 houses having a "high" RVI score, built only a few metres from the shoreline at Piscità and Punta Lena, and 10 buildings having an "average" RVI score. The PTVA-3 Model did not assign the maximum RVI score (RVI - "very high") to any of the structures studied.

Whilst the average structural vulnerability level of the built environment on Stromboli and Panarea is not critical, the tsunami would affect different types of buildings and cause the interruption or the delay of important socio-economic activities (e.g. tourism and commercial activities, public and emergency services, etc.). RVI scores of different types of buildings are shown in Table 3. Based on these results, the following important observations can be made:

- Most of the affected buildings are residential, although a subset of them might be rented to tourists from May to September. During field surveys it was no possible to find out which of them is used as tourist accommodation during the summer.

- If the 2002 tsunami occurred today, there would be noticeable impact on the tourism economy, even if only $10 \%$ of the inundated buildings are hotels and/or related utilities. Furthermore, if the event occurred in the high 


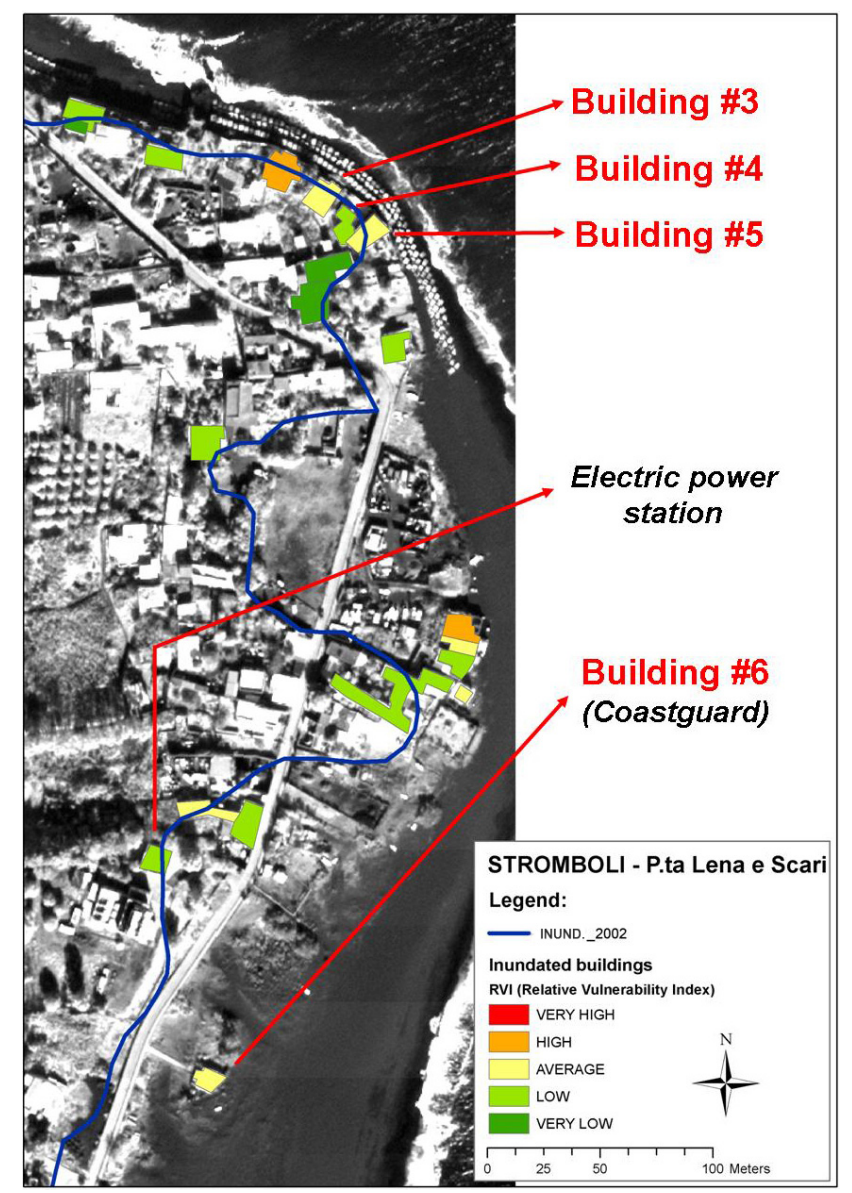

Fig. 6. Vulnerability map of Punta Lena (north) and Scari (south), Stromboli Island. The map layout corresponds to the red frame in Fig. 2. The blue line marks the limit of maximum inundation caused by the 2002 tsunami. Buildings from \#3 to \#6 have been used to validate the PTVA-3 Model results. Damage suffered by these buildings during the 2002 tsunami are shown in Figs. 10-13.

seasons, general damage and chaos could cause a negative impact on the economy related to tourism.

- Commercial activities that would be hit are mostly connected with tourism (restaurants, souvenir shops, fishing and sailing shops, etc.). Such buildings have been classified as being moderately vulnerable, and so they are not expected to suffer significant structural damage. However, the flood would cause a partial destruction of the goods stored inside and also the interruption of commercial activities.

- Only one inundated building belongs to the "utility" class. It is the only electrical power station on the island of Stromboli (division of Scari). Although its vulnerability is "low", damage by even minor inundation could be significant enough to cause the loss of power throughout the island, complicating post-disaster operations. This highlights the importance of ground

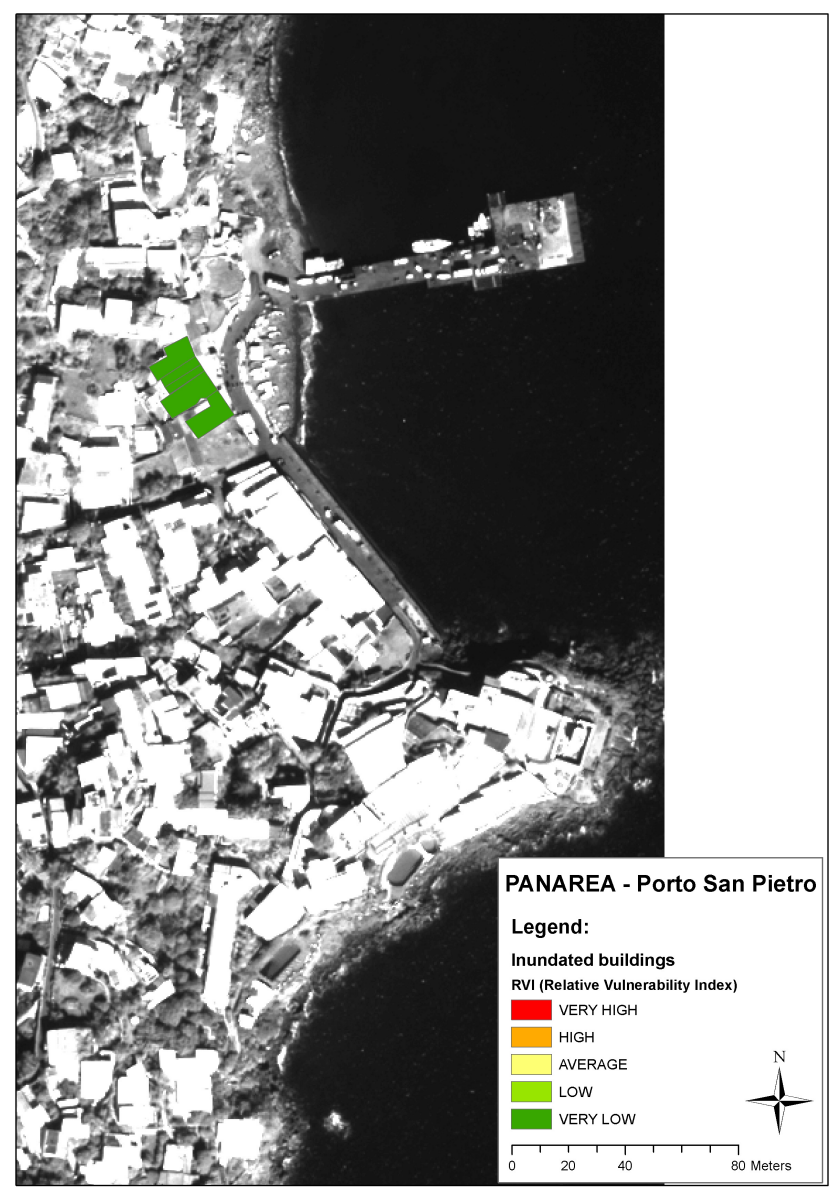

Fig. 7. Vulnerability map of the San Pietro Harbour (Panarea Island). The tsunami would inundate only 5 commercial buildings behind the main pier. Their RVI scores are all "very low". The flow depth in this area would not exceed $1 \mathrm{~m}$.

truthing, because the RVI score does not depend on the strategic importance of the building and its use, and this is why the PTVA-3 Model classified the power station structure as having a "very low" vulnerability.

- The Coastguard building in Scari (building \#6) is another "critical" building that should be fully operational in case of a tsunami. The relevant Public Administration (PA) office might want to consider appropriate prevention measures for such a strategic building.

- Luckily, no buildings located in the inundated area belong to the categories of "health" (i.e. hospitals, medical centres, pharmacies, etc.), "education" (i.e. schools, nurseries, etc.), "public transport" (apart from the pier of the Stromboli and San Pietro harbours) and "culture and recreation centres" (i.e. churches, museums, libraries, historical buildings, sport centres, etc.). 
In addition to observations on different type of affected buildings, results from the PTVA-3 Model and observations during field surveys suggested a set of general prevention and mitigation measures that could help further reduce the overall vulnerability level.

In the area of Punta Lena, for example, the most important issues involve buildings located a few metres from the shoreline. The development of such areas should be avoided in future urban planning, because construction would not only increase the tsunami risk but also be inconsistent with most of the Integrated Coastal Zone Management (ICZM) principles (CEC, 1999).

The presence of large movable objects (e.g. cars, trucks, boats) within the inundated zones is another important issue that could be addressed by the archipelago community. Such objects can be transported by the flow and hit buildings or injure people, causing severe damage. Boats stored on land, seaside parking areas for cars and bikes for rent, large garbage bins and containers behind the beaches of Scari and Punta Lena (Stromboli) all combine to increase the RVI scores of surrounding buildings. Some of the residents interviewed during field surveys claimed that most of those boats are never used and have been abandoned on the beach.

\subsection{Validating the PTVA-3 Model results}

Whilst the original version of the PTVA Model has been validated during post-tsunami field surveys on the Maldives (Dominey-Howes and Papathoma, 2007), we undertook a further validation to confirm the accuracy of PTVA-3, the recently improved, next-generation of the model. For six buildings on Stromboli we could compare results forecast by the model with the damage suffered by the same buildings during the 2002 tsunami. The comparison has been carried out on a visual base, using pictures taken by the INGV and the University of Bologna during the post-tsunami field surveys in early January 2003 for reference. Buildings used for the validation of the model have been numbered from \#1 to \#6 and marked with red symbols on the vulnerability maps of Stromboli island (Figs. 4-6).

Figure 8 shows the façade of building \#1 after the 2002 tsunami. The footprint of the same building is highlighted in the vulnerability map of Piscità (Fig. 4). Although the picture provides only a partial view, no relevant damage can be seen, except from an unhinged window on the first floor. Building \#1 is located on the coastal cliff and intersects the line of maximum horizontal water inundation. Accordingly, the water depth impacting the building was minimal and did not even flood the whole ground-floor. Damage to the interior and to parts vulnerable to water contact was negligible. The RVI score calculated by the PTVA-3 Model for that building is "very low" and result are thus consistent with the observed damage.

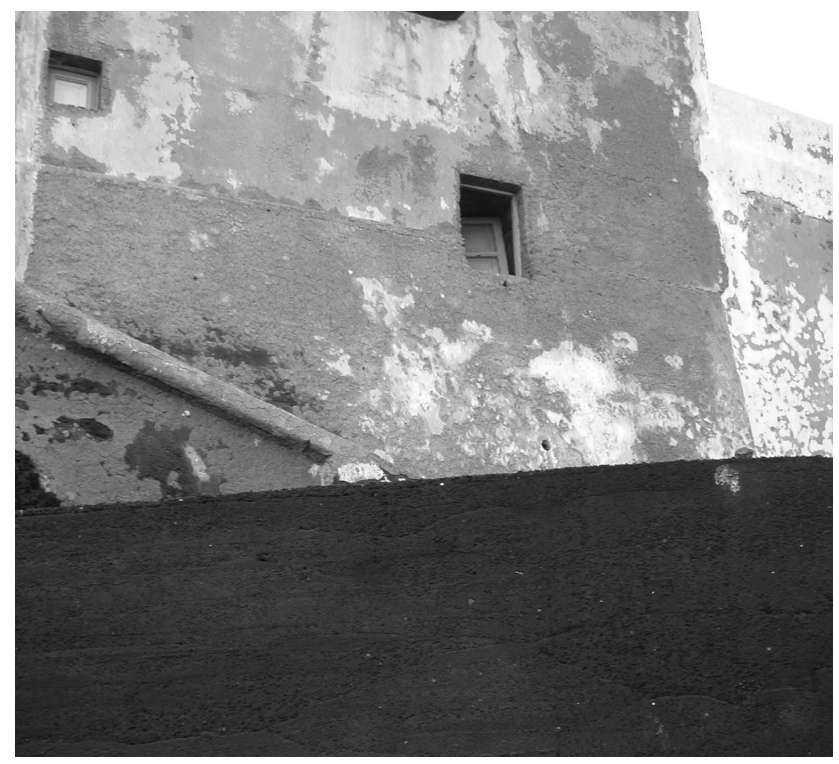

Fig. 8. View from north-west of building \#1, at Piscità (Stromboli - Fig. 4). The picture was taken few days after the 2002 tsunami. The only visible damage is an unhinged window on first floor. The PTVA-3 Model classified building \#1 as having a "very low" RVI score which correlates well with the actual damage sustained by this building.

Damage to building \#2, at Ficogrande (Fig. 5), is shown in Fig. 9. The flow broke through a door in the front wall, penetrated indoors, destroyed the interior and one partition wall and travelled through the backdoor of the house (Tinti et al., 2006a). The overall damage level is clearly heavier than the one observed in building \#1 at Piscità. The PTVA-3 Model classified building \#2 as having an "average" RVI. Although such an RVI score may appear to be an underestimate, Fig. 9 shows that no damage occurred to the weight-bearing walls of the building. Apart from an internal partition wall, which is not designed to withstand any kind of pressure, damage involved only doors, windows, furniture (which is not considered by the PTVA-3 Model) and the interior, especially parts vulnerable to water (electric appliances, fixtures, paving tiles, etc.).

In Punta Lena and Scari, we could check the accuracy of the PTVA-3 Model results for four buildings (buildings \#3 to \#6) (Fig. 6). Three of them (buildings \#3 to \#5) are residential houses located a few $\mathrm{m}$ from the sea at Punta Lena. Building \#6, in Scari, is the Coastguard station.

Buildings \#3, \#4 and \#5 have very similar construction characteristics: they are single-storey, bricks-made and have a partially open ground-floor with windows. According to INGV and University of Bologna surveys, during the 2002 tsunami the inundation depth at buildings \#3 and \#5 was between 1 and $2 \mathrm{~m}$, while at building \#4 the flow was shallower (about $1 \mathrm{~m}$ ). 


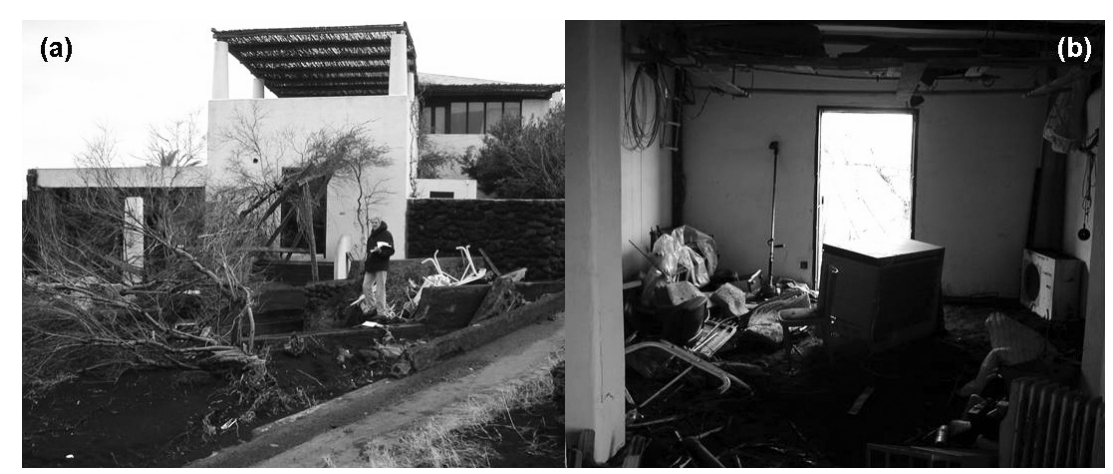

Fig. 9. Pictures of building \#2, at the eastern end of Ficogrande (Stromboli - Fig. 5), taken after the 2002 tsunami. (a) A view of the building from north-west. (b) Damage to the interior. The PTVA-3 Model classified building \#2 as having an "average" RVI score.

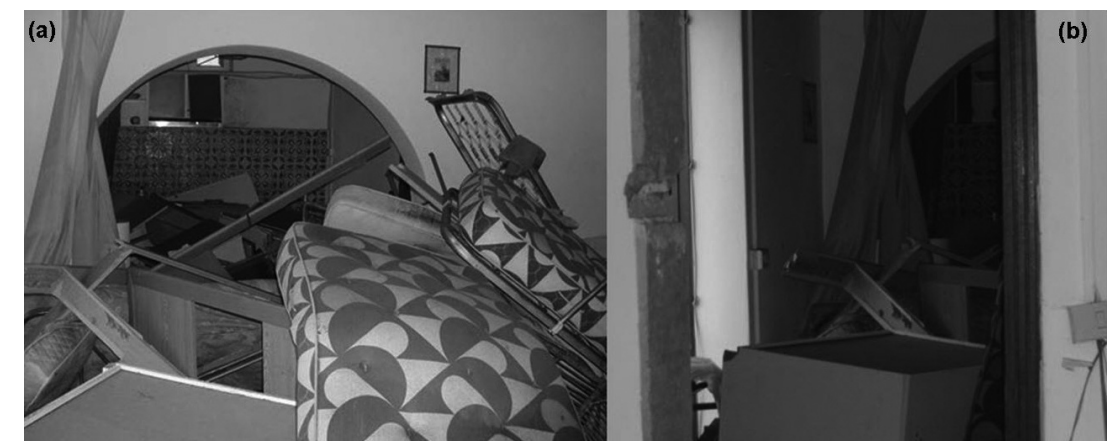

Fig. 10. Two pictures of building \#3 (Punta Lena, Stromboli - Fig. 6) taken after the 2002 tsunami. (a) Damage to the interior. (b) A view of the main entrance of the building, where the door have been ripped off the wall. The PTVA-3 Model assigned to building \#3 an "average" RVI score.

Damage to building \#3 (RVI = "average") is shown in Fig. 10. The flow broke through doors and windows and caused total destruction to the interior. However, there is no evidence of damage to the load-bearings walls. The overall damage level is thus comparable to building \#2 at Ficogrande.

Damage to building \#4 (RVI = "low") is partially shown in Fig. 11. The front door has not been broken-down and suffered only minor damage. However, the water penetrated indoors through the shutter openings and flooded the groundfloor, causing damage to the interior. The overall impact on the structure was lighter than for neighbouring buildings. This was due to shallow inundation depth and to the protection provided by the front-garden vegetation and some artificial structures between the building and the sea (a brick wall, a large concrete table in the garden and the coastal defences along the shoreline) (Fig. 11b). As forecast by the PTVA-3 Model, such protection slowed down the flow and prevented some of the floating debris from impacting the building structure.

Figure 12 shows damage to building \#5 (RVI = "average"). Like building \#2 and 3, window and door frames have been ripped off the wall. The building interior has been completely destroyed and the contents widely dispersed. The im- pact caused a crack in the front-wall, but left load-bearing column to its right undamaged (Fig. 12b). The front-porch has been almost completely destroyed. However, the loadbearing structure of the building is largely untouched.

Building \#6, the Coastguard station, is situated on Scari beach (Fig. 6). It has one storey, a brick-made structure and a ground-floor almost completely closed, with no openings on the seaward wall. There is no protection from the sea apart from a coastal dune that rests against the seaward side of the building. The RVI score of building \#6 is "average". Figure 13 shows a picture of the building taken few days after the 2002 tsunami. Whilst the picture does not provide a detailed view of the structure, it appears that the general damage level is lighter than that observed in buildings \#2, \#3 and \#5, although they have the same RVI score. This is due to the relative position of the building and the coastal dune. The shielding effect provided by the dune was higher than predicted by the model, which is designed to consider the protection from natural defences but does not include such particular cases. However, whilst building \#6 was well protected against the first impact of the tsunami, it has been inundated by more than $1 \mathrm{~m}$ of water. As a consequence, some damage to the interior must have occurred, although this was not recorded and cannot be seen in the photograph (Fig. 13). 

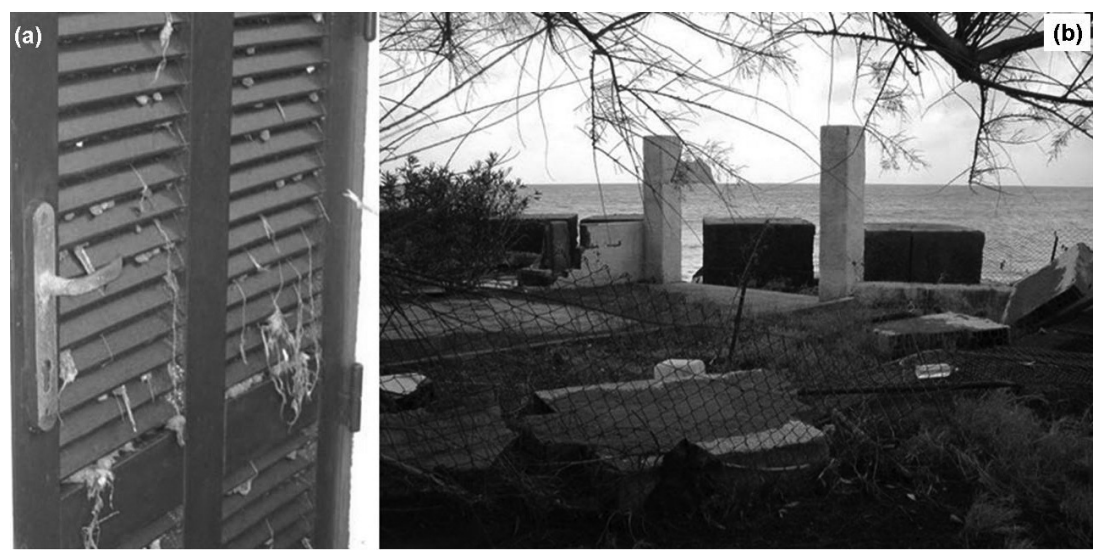

Fig. 11. Two pictures of building \#4 (Punta Lena, Stromboli - Fig. 6), taken after the 2002 tsunami. (a) A door on the seaward wall of the building. The inundation did not break it down, but penetrated through the shutter openings and flooded the ground-floor. The building was protected by the vegetation in the front garden (b), some concrete works (a small wall and a table) and by the costal defences along the shoreline (concrete cubic rocks). The PTVA-3 Model classified this building as having a "low" RVI.

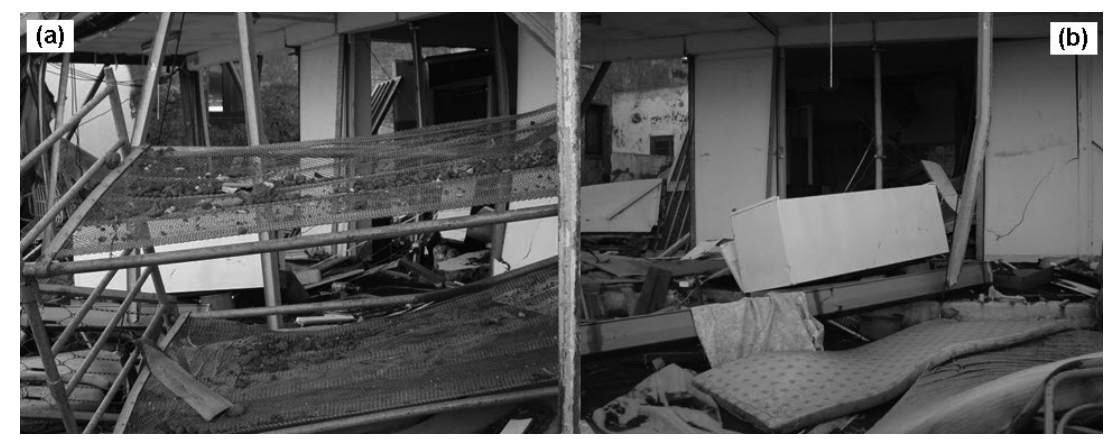

Fig. 12. Two pictures of building \#5 (Punta Lena, Stromboli - Fig. 6) taken after the 2002 tsunami. The flow broke doors and windows, penetrated indoors and dragged the building contents outside (a). A large crack can be observed in the front side wall (b). However, that wall does not appear to be part of the load-bearing structure of the building, as does the undamaged column at its right. The PTVA-3 Model classified building \#5 as having an "average" RVI score.

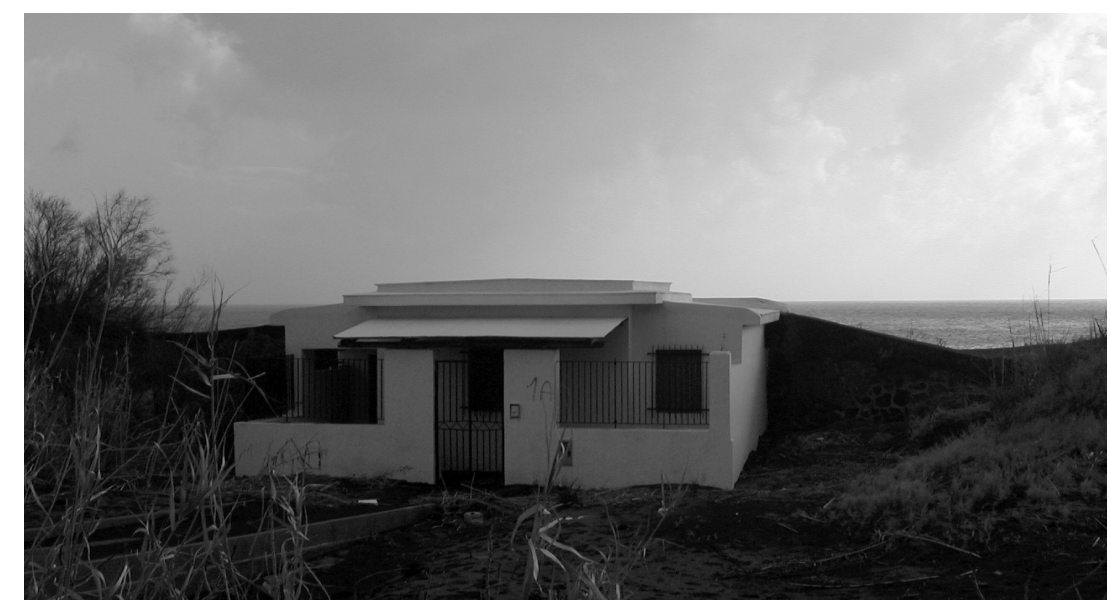

Fig. 13. View of the western side of building \#6. The picture was taken a few days after the 2002 tsunami. Building \#6 is a Coastaguard station on the beach of Scari (Stromboli - Fig. 6). As clearly shown by the picture, the seaward side of the building is totally "covered" by a coastal dune. The PTVA-3 Model attributed to building \#6 an "average" RVI score. 
From the results presented in our analysis, it is clear that the forecast capability of the PTVA-\# Model matches well with actual damage sustained by buildings during a real tsunami. This high correlation increases our confidence in the power of the PTVA-3 Model as a forecast building tsunami vulnerability assessment tool.

\section{Conclusions}

We applied the newly developed PTVA-3 Model (Papathoma Tsunami Vulnerability Assessment Model, version 3) to assess the vulnerability to tsunami of buildings at the Aeolian Islands, in Italy. Since 1916, the Aeolian Islands have been hit by 8 local tsunamis, the most recent in December 2002 . Given the current lack of a probabilistic tsunami assessment for the study area, we adopted the 2002 inundation as a deterministic scenario.

Results show that if the 2002 tsunami happened today, 54 buildings would be hit on Stromboli and 5 on Panarea. According to PTVA-3 Model output, the overall vulnerability level of such structures is "average/low" (Table 3). However, 14 buildings have been classified as having "high" and "average" RVI scores. Those structures would be severely affected by the tsunami. Where possible, the Public Administrations should prearrange actions aimed to reduce their vulnerability. Based on the PTVA-3 Model results and observations undertaken during field surveys, some specific prevention measures have been suggested. Whilst the high tsunami risk of the Aeolian archipelago is well known, the vulnerability of buildings had never been assessed before the present work. Therefore, we believe our results can be of help to the local communities and Public Administration, because key building vulnerabilities are identified and possible actions to increase the overall resilience of the built environment are proposed.

The vulnerability assessment undertaken here is entirely based on the application of the PTVA-3 Model. The PTVA3 is the latest version of the original PTVA Model (Papathoma et al., 2003; Papathoma and Dominey-Howes, 2003) and it was recently developed and applied in Australia by Dall'Osso et al. (2009a,b). Before being used in the present work, the PTVA-3 Model had to be adapted to the construction standards of Aeolian Islands. However, since every factor considered by the PTVA-3 Model can be independently modified, the required adjustments have been easily introduced, confirming the flexibility of the model.

Data required for the assessment have been extracted from two high resolution satellite images and through field surveys. Once available, data have been stored and organised within a GIS. The computation of the RVIs was automatically performed through a specific tool for ESRI ArcGIS, developed by Dall'Osso and Dominey Howes (2009a).
For some buildings we were able to validate the PTVA3 Model results by comparison with pictures of the damage they suffered during the 2002 tsunami. Apart from the Coastguard building in Scari (Stromboli), the PTVA-3 Model was found to be an accurate assessment of the observed damage. In particular, three buildings classified as having an "average" RVI score showed the same overall damage level (i.e. high damage to doors and windows, flooding of the groundfloor, destruction of the interior, damage to some partition walls but no relevant damage to the load-bearing structure). Furthermore, the model showed a good degree of precision, as it was able to differentiate the RVIs of three houses at Punta Lena (Fig. 6), whilst they have very similar construction characteristics and are located very close to each other. With regard to the Coastguard station, damage observed in the available picture appears to be lighter than those suffered by other buildings having the same RVI score. The most likely reason for the difference was the protection provided by a $2 \mathrm{~m}$ high dune that nearly covered the entire seaward side of the building. Whilst the PTVA-3 Model considers the shielding effect from natural defences, it is not designed to provide for such particular cases, which would require a numerical simulation of the flooding.

A previous version of the PTVA Model (PTVA-2) has already been validated during post-tsunami field surveys at the Maldives (Dominey-Howes and Papathoma, 2007). This further validation confirmed the accuracy of version 3 of the model, which implements some important improvements based on recent publications, not available when the original PTVA was first developed. Future generations of the model should aim to implement a numerical simulation of the tsunami flooding, at a scale consistent with the size of single buildings. Furthermore, the PTVA-3 Model does not include data on building fragility curves, because at the moment no exhaustive and fully validated engineering models are yet available. However, the present work demonstrates that the PTVA-3 Model is able to provide an accurate assessment of the relative vulnerability of buildings to tsunami damage and it can be easily applied to different study areas, filling the gap until fragility curves for different types of building are developed and implemented.

Acknowledgements. This research was partially funded by the TRANSFER EU Project. We would like to thank the Stromboli Public Administration for giving us an essential support during field surveys. We would also like to thank Dave Anning and Dale Dominey-Howes for his help in revising an earlier version of this paper. We wish to thank the referees for their contribution.

Edited by: I. Didenkulova

Reviewed by: J. Goff and another anonymous referee 


\section{References}

Ambraseys, N. N.: Data for the investigation of the sesimic seawaves in the eastern Mediterranean, B. Seismol. Soc. Am., 52, 895-913, 1962.

Baldi, P., Belloli, F., Fabris, M., Marsella, M., Ponticelli, R., and Signorotto, V.: Fotogrammetria digitale differenziale del versante della Sciara del Fuoco (Isola di Stromboli) dopo l'evento del 30 Dicembre 2002. 7a Conferenza nazionale ASITA "L'informazione territoriale e la dimensione del tempo", Verona, 28-31 Ottobre 2003 (in Italian).

Barberi, F., Gasparini, P., Innocenti, F., and Villari, L.: Volcanism of the southern Tyrrhenian sea and its geodynamic implications, J. Geophys. Res., 78, 5221-5232, 1973.

Barberi, F., Rosi, M., and Sodi, A.: Volcanic hazard assessment at Stromboli based on review of historical data, Acta Vulcanologica, 3, 173-187, 1993.

Beccaluva, L., Gabbianelli, G., Lucchini, F., Rossi, L., and Savelli, C.: Petrology and K/Ar ages of volcanics dredged from the Eolian seamounts: implications for geodynamic evolution of the southern Tyrrhenian basin, Earth Planet. Sc. Lett., 74, 187-208, 1985.

Bosman, A., Chiocci, F. L., Romagnoli, C., Tommasi, P., Abballe, P., Bellino, M., De Alteris, G., D'Isanto, C., Macelloni, L., and Tondelli, R.: Evoluzione morfologica e deposizionale del settore sommerso antistante la Sciara del Fuoco a partire dall'evento di maremoto del 30/12/2002: implicazioni per la comprensione dei fenomeni di instabilita' gravitativi, GNV General Assembly, Rome, 9-11 June 2003 (in Italian).

Burton, M., Allard, P., Murè, A., and La Spina, A.: Magmatic gas composition reveals the source depth of slug driven Strombolian explosive activity, Science, 317(5835), 227-230, 2007.

CEC (Commission of the European Communities): Towards a European Integrated Coastal Zone Management (ICZM) Strategy General Principles and Policy Options, CEC, Luxembourg, 1999.

Chiocci, F. L., Bosman, A., Romagnoli, C., Tommasi, P., and De Alteris, G.: The December 2002 Sciara del Fuoco (Stromboli Island) submarine landslide: a first characterisation, EGS-AGUEGU Joint Assembly, Nice, France, April 2003, Geophysical Research Abstracts, Vol. 5, CDROM Version, 2003.

Dall'Osso, F. and Dominey-Howes, D.: A method for assessing the vulnerability of buildings to catastrophic (tsunami) marine flooding, ArcGIS toolbox - User Manual. UNSW, 44 pp., available at: http://www.sydneycoastalcouncils.com.au/ (last access: May 2010), 2009a.

Dall'Osso, F. and Dominey-Howes, D.: A method for assessing the vulnerability of buildings to catastrophic (tsunami) marine flooding, unpublished report, 139 pp., available at: http://www. sydneycoastalcouncsils.com.au (last access: May 2010), 2009b.

Dall'Osso, F., Cavalletti, A., and Polo, P.: Risk assessment and evaluation ArcGIS ${ }^{\circledR}$ toolbox: User's Manual, available at: http://www.adpc.net/v2007/Downloads/2007/May/ RISK\%20ASSESSMENT\%20AND\%20EVALUATION\% 20A5_for_print.pdf (last access: May 2010), 2006.

Dall'Osso, F., Gonella, M., Gabbianelli, G., Withycombe, G., and Dominey-Howes, D.: A revised (PTVA) model for assessing the vulnerability of buildings to tsunami damage, Nat. Hazards Earth Syst. Sci., 9, 1557-1565, doi:10.5194/nhess-9-1557-2009, 2009a.
Dall'Osso, F., Gonella, M., Gabbianelli, G., Withycombe, G., and Dominey-Howes, D.: Assessing the vulnerability of buildings to tsunami in Sydney, Nat. Hazards Earth Syst. Sci., 9, 2015-2026, doi:10.5194/nhess-9-2015-2009, 2009b.

Dominey-Howes, D. and Papathoma, M.: Validating a Tsunami Vulnerability Assessment Model (the PTVA Model) Using Field Data from the 2004 Indian Ocean Tsunami, Nat. Hazards, 40, 113-136, 2007.

Dominey-Howes, D., Dunbar, P., Verner, J., and PapathomaKöhle, M.: Estimating probable maximum loss from a Cascadia tsunami, Nat. Hazards, 53, 43-61, 2010.

IOC/UNESCO (Intergovernmental Oceanographic Commission): Post-tsunami survey field guide, 1st edn., UNESCO, Manuals and Guides n. 37, 1998.

Maramai, A., Graziani, L., and Tinti, S.: Tsunamis in the Aeolian Islands (southern Italy): a review, Mar. Geol., 215, 11-21, 2005a.

Maramai, A., Graziani, L., Alessio, G., Burrato, P., Colini, L., Cucci, L., Nappi, R., Nardi, A., an dVilardo, G.: Near- and farfield survey report of the 30 December 2002 Stromboli (Southern Italy) Tsunami, Mar. Geol., 215, 93-206, 2005b.

Matsutomi, H., Sakakiyama, T., Nugroho, S., Matsuyama, M.: Aspects of inundated flow due to the 2004 Indian Ocean tsunami, Coastal Engineering Journal, 48, 2, 167 -195, 2006.

Papathoma, M., Dominey-Howes, D., Zong, Y., and Smith, D.: Assessing tsunami vulnerability, an example from Herakleio, Crete, Nat. Hazards Earth Syst. Sci., 3, 377-389, doi:10.5194/nhess-3377-2003, 2003.

Papathoma, M. and Dominey-Howes, D.: Tsunami vulnerability assessment and its implications for coastal hazard analysis and disaster management planning, Gulf of Corinth, Greece, Nat. Hazards Earth Syst. Sci., 3, 733-747, doi:10.5194/nhess-3-7332003, 2003.

Pasquarè, G., Francalanci, L., Garduño, V. H., and Ribaldi, A.: Structure and geological evolution of the Stromboli volcano, Aeolian Islands, Italy, Acta Vulcanologica, 3, 79-89, 1993.

Pino, N. A., Ripepe, M., and Cimini, G. B.: The Stromboli volcano landslides of December 2002: a seismological description, Geophys. Res. Lett, 31, L02605, doi:10.1029/2003GL0118385, 2004.

Reese, S., Cousins, W. J., Power, W. L., Palmer, N. G., Tejakusuma, I. G., and Nugrahadi, S.: Tsunami vulnerability of buildings and people in South Java - field observations after the July 2006 Java tsunami, Nat. Hazards Earth Syst. Sci., 7, 573-589, doi:10.5194/nhess-7-573-2007, 2007.

Rosi, M., Bertagnini, A., and Landi, P.: Onset of the persistent activity at Stromboli volcano (Italy), B. Volcanol., 62, 294-300, 2000.

Olwig, M. F., Sorensen, M. K., Rasmussen, M. S., Danielsen, F., Selvams, V., Hansen, L. B., Nyborg, L., Vestergaard, K. B., Parish, F., and Karunaganas, V. M.: Using the remote sensing to assess the protective role of coastal woody vegetation against tsunami waves, Int. J. Remote Sen., 28(13-14), 31533169, 2007.

Saaty, T. L.: Axiomatic foundation of the Analytic Hierarchy Process, Manage. Sci., 32, 841-855, 1986.

Sieberg, A: Geologiche, physikalische und angewandte Erdbebenkunde, Verlag von Gustav Fischer, Jena, 1927. 
Tanaka, N., Sasaki, Y., Mowjood, M. I. M., Jinadasa, K. B. S. N., and Homchuen, S.: Coastal vegetation structures and their functions in tsunami protection: experience of the recent Indian Ocean tsunami, Landsc. Ecol. Eng., 3, 33-45, 2007.

Tinti, S., Manucci, A., Pagnoni, G., Armigliato, A., and Zaniboni, F.: The 30 December 2002 landslide-induced tsunamis in Stromboli: sequence of the events reconstructed from the eyewitness accounts, Nat. Hazards Earth Syst. Sci., 5, 763-775, doi:10.5194/nhess-5-763-2005, 2005.

Tinti, S., Maramai, A., Armigliato, A., Graziani, L., Manucci, A., Pagnoni, G., and Zaniboni, F.: Observations of physical effects from tsunamis of December 30, 2002 at Stromboli volcano, southern Italy, B. Volcanol., 68, 450-461, 2006a.
Tinti, S., Pagnoni, G., and Zaniboni, F.: The landslides and tsunamis of 30th December 2002 in Stromboli analysed through numerical simulations, B. Volcanol., 68(5), 462-479, 2006b.

UNESCO: UNESCO World Heritage List, available at: http://whc.unesco.org/en/list, last access: September 2009.

USGS: Volcano Hazard Program, available at: http://volcanoes.usgs.gov/images/pglossary/strombolian.php, last access: September 2009. 